\title{
Physicochemical composition, color and sensory acceptance of low-fat cupuaçu and açaí nectar: characterization and changes during storage
}

\author{
Eneide Taumaturgo Macambira Braga FERNANDES ${ }^{1}$, Vlayrton Tomé MACIEL ${ }^{2}$, Maria Luzenira de SOUZA³, \\ Cydia de Menezes FURTADO ${ }^{3}$, Lucia Helena de Oliveira WADT ${ }^{4}$, Clarissa Reschke da CUNHA ${ }^{5 *}$
}

\begin{abstract}
This study aimed to evaluate the physicochemical composition, color and sensory acceptance of low-fat açaí and cupuaçu nectar, as well as changes in these parameters during storage. Nectars were prepared with açaí pulp previously defatted by centrifugation on a pilot scale. The study consisted of two steps. In the first step, the physicochemical characteristics, instrumental color, and sensory acceptance of the nectar prepared with low-fat açaí pulp were evaluated and compared with those of nectar prepared with full-fat açaí pulp. In the second step, titratable acidity, $\mathrm{pH}$, soluble solids, anthocyanin content, instrumental color, and sensory acceptance of the low-fat açaí and cupuaçu nectar were evaluated for 6 months of storage at $25^{\circ} \mathrm{C}$ in the absence of light. The use of low-fat açaí pulp resulted in nectars with good overall acceptance, but with lower scores for color acceptance than those of the full-fat nectar. The low-fat nectar remained stable with respect to acidity, $\mathrm{pH}$, and soluble solid content during storage for up to 180 days. However, there was degradation of anthocyanins, which had a negative impact on the product color and sensory acceptance over time. Under the conditions evaluated, the estimated product shelf life is up to 120 days.
\end{abstract}

Keywords: Euterpe precatoria; nectar; low fat; sensory acceptance.

Practical Application: This study proposes the formulation of a mixed fruit nectar using two raw materials from the Amazon region, açaí and cupuaçu, which is an interesting way to add value to this type of product. Additionally, it proposes the use of defatted açaí pulp, meeting the increasing consumers' preference for healthier foods containing functional compounds and that are low in fat.

\section{Introduction}

The açaí palm tree is native to the Amazon. Its fruits are used to produce the açaí pulp, a foodstuff widely consumed by the local people (Souza et al., 1999). In recent years, there has been a significant increase in demand for this product in the domestic and international markets due to the nutritional properties of açaí berry, which has high levels of lipids, proteins, fiber, vitamin E, and minerals (Alexandre et al., 2004). Açaí is also rich in anthocyanins, pigments with antioxidant properties that have been associated with various health benefits (Albarici \& Pessoa, 2012; Pacheco-Palencia et al., 2009; Del-Pozo-Insfran et al., 2006; Rogez, 2000).

Açaí fruits are immersed in warm water for pulp removal. Pulp extraction can be done manually or mechanically, with or without the addition of water (Rogez, 2000). The unprocessed açaí pulp is highly perishable due to rapid microbial contamination and enzymatic deterioration, which cause color changes and the development of a sour taste. (Souza et al., 1999; Queiroz et al., 1998).

Despite the well-known functional and nutritional properties of the açaí berry, there is little variety of products made from its pulp available. Many studies have been conducted in order to obtain products derived from açai, such as juices, dehydrated products, etc. (Cruz et al., 2011; Tonon et al., 2009; Menezes et al., 2008; Carvalho, 2007; Sousa et al., 2006). Although the results of these studies are promising, there are still many issues to be addressed, such as sensory acceptance of products, standardization of the processing conditions, and the maintenance of the functional properties during processing and storage.

An alternative way to add value to the açaí pulp and promote its consumption is to use it as an ingredient in nectar formulation. Therefore, Embrapa researchers have developed a nectar of açaí and cupuaçu (Empresa Brasileira de Pesquisa Agropecuária, 2006), in which cupuaçu pulp has a dual function: to impart flavor and to reduce the final $\mathrm{pH}$, thus eliminating the need for adding synthetic acidulants. However, this açaí-based nectar developed has disadvantages such as high energetic value (180-200 kcal/200 g) and high fat content (3.5-4.0\%), which are much higher than those found in common juices and fruit nectars. These characteristics are contrary to the wishes of many consumers, who are increasingly looking for low-fat and

${ }^{1}$ Rede Bionorte, Universidade Federal do Acre - UFAC, Rio Branco, AC, Brazil

${ }^{2}$ Embrapa Acre, Rio Branco, AC, Brazil

${ }^{3}$ Unidade de Tecnologia de Alimentos - UTAL, Centro de Ciências Biológicas e da Natureza, Universidade Federal do Acre - UFAC, Rio Branco, AC, Brazil

${ }^{4}$ Embrapa Rondônia, Porto Velho, RO, Brazil

${ }^{5}$ Embrapa, Parque Estação Biológica, Brasília, DF, Brazil

*Corresponding author: clarissa.cunha@embrapa.br 
low-calorie food products. It would therefore be interesting to produce a nectar using defatted açaí pulp in order to obtain a low-fat functional product with antioxidant capacity.

In view of the above considerations, the present study aimed to evaluate the physicochemical composition, color, and sensory acceptance of low-fat açaí and cupuaçu nectar, as well as changes in these parameters during storage.

\section{Materials and methods}

\subsection{Preparation of açaí and cupuaçu nectar}

The following ingredients were used in the preparation of nectars: cupuaçú pulp, açaí pulp, guarana syrup (Cia. Hemmer Ind. Com. Ltda., Blumenau, SC, Brazil), sugar (Usinas Itamarati S.A., Nova Olimpia, MT, Brazil), glucose (Yoki, General Mills Brasil Alimentos Ltda., São Bernardo do Campo, SP, Brazil), and mineral water. The frozen açaí pulp (Euterpe precatoria) was obtained in the municipality of Feijó-AC. The frozen pasteurized cupuaçú pulp (Cooperacre, Rio Branco, AC, Brazil) was purchased from the local market. Since this study involved the access to the national genetic heritage, the research project was submitted to evaluation by competent authorities (IBAMA), from whom authorization was granted. (Process number 02001.000664/2012-36). The composition of the nectars, previously defined in preliminary tests, was as follows: $12.5 \%$ cupuaçu pulp, $58.4 \%$ açaí pulp, $1.9 \%$ guarana syrup, $6.7 \%$ sugar, $3.0 \%$ glucose, and $17.5 \%$ water. The ingredients were first homogenized using an industrial blender for 5 minutes; they were then preheated to $80^{\circ} \mathrm{C}$ for 3 minutes and hot filled into glass bottles. The bottles were sealed, and the nectars were autoclaved at $115^{\circ} \mathrm{C}$ for 10 minutes and stored in a BOD incubator at $25^{\circ} \mathrm{C}$ and in the absence of light.

\subsection{Step 1 -Quality of nectar prepared with low-fat açaí pulp in comparison with the nectar prepared with full-fat açaí pulp}

The açaí pulp was divided into two batches: the first one did not undergo any pre-treatment, while the second one was subjected to a defatting step at $50{ }^{\circ} \mathrm{C}$ in a disc stack separator (Model D1000, RN Centrifuges Ltda., Piracicaba, Brazil). Full-fat açaí pulp and low-fat açaí pulp were used as raw materials. The final products were analyzed for physicochemical characteristics, instrumental color, microbiological safety, and sensory acceptance. A randomized block design was adopted. The factor studied was the fat content of açaí pulp (low-fat and full-fat pulps). These two experiments were performed in triplicate. The results were analyzed by ANOVA and the Tukey test at $5 \%$ significance.

\subsection{Step 2 - Changes during storage of the low-fat açaí and cupuaçu nectar}

In this step, the nectars were prepared with low-fat açaí pulp, obtained as described above. The final products were stored in a BOD incubator at $25^{\circ} \mathrm{C}$ and in the absence of light, and evaluated as follows: a) immediately after preparation - for physicochemical composition, microbiological safety, instrumental color, and sensory acceptance; b) on days 30, 60, 90, 120, 150, and 180 after preparation - for titratable acidity, $\mathrm{pH}$, soluble solids, anthocyanins, microbiological safety, and instrumental color. A randomized block design was adopted. The factor studied was time of storage. The experiment was performed in triplicate. The results were analyzed by ANOVA and the Tukey test at 5\% significance. Furthermore, for one of the replicates, the sensory evaluations were performed every 2 months (on days $0,60,120$, and 180 after nectar preparation).

\subsection{Physicochemical characterization of raw materials and nectars}

The cupuaçu and açaí pulps and the nectars were analyzed for: titratable acidity (Intituto Adolfo Lutz, 1985); pH, using a direct reading digital meter; soluble solids ( $\left.{ }^{\circ} \mathrm{Brix}\right)$, using a digital refractometer; moisture; total protein using the Kjeldahl method and the conversion factor of 6.25; lipids, using the Soxhlet method; ash; total fiber, quantified in previously defatted samples, followed by the enzymatic method (Association of Offical Analitical Chemists, 1998); and total carbohydrates, determined by difference. The açaí pulps and the nectars were also evaluated for anthocyanin content, according to Francis (1982). Anthocyanins were extracted in $1 \mathrm{~mL}$ of the sample with a solution of ethanol and $\mathrm{HCl}(1.5 \mathrm{M}$ ) (in the ratio 85:15). After a night rest under refrigeration and total absence of light, the extracts were filtered and the absorbance was measured in a spectrophotometer at $535 \mathrm{~nm}$.

\subsection{Microbiological analysis of nectars}

The nectars were evaluated for total and thermotolerant $\left(45^{\circ} \mathrm{C}\right.$ ) coliforms (MPN g $\left.{ }^{-1}\right)$, and salmonella sp, as described by Vanderzant \& Splittstoesser (1992), in order to ensure the safety of the panelists before sensory evaluation. The detection limit was $3 \mathrm{MPN} \mathrm{g}^{-1}$ for coliforms.

\subsection{Instrumental color}

Instrumental color evaluation was performed using the Konica Minolta CM-600 colorimeter (Konica Minolta Sensing Americas, Inc., NJ, USA). The color scale used was the CIELAB $\left(\mathrm{L}^{*}, \mathrm{a}^{*}, \mathrm{~b}^{*}\right)$, with the illuminant D65 and angle of $10^{\circ}$. The equipment operated in the reflectance mode, and the readings were carried out using a $10-\mathrm{mm}$ quartz cuvette for liquid analysis. The values of the parameters $L^{*}, a^{*}$, and $b^{*}$ (CIELAB scale) were obtained. All determinations were carried out in triplicate.

\subsection{Sensory acceptance}

The sensory acceptance tests were performed using the monadic presentation technique (Meilgaard et al., 2006). Forty untrained consumers (18-50 years) evaluated the nectars. The study was approved by the Research Ethics Committee (resolution \# 196/96, October $10^{\text {th }}, 1996$, Brazilian National Health Council - protocol number CAAE 00610112.8.0000.5010). Sensory evaluations were carried out only after the conclusion of the physicochemical and microbiological determinations. Only samples in accordance with the Brazilian legislation regarding 
microbiological contamination (Brasil, 2001) were evaluated. The panelists were asked to read and sign an Informed Consent Form before performing the analyses. The samples were assessed by the panelists in individual booths under white light. Approximately $30 \mathrm{ml}$ of each sample were served at $10^{\circ} \mathrm{C}$ in plastic cups coded with 3-digit numbers. In Step 1, each panelist evaluated two samples, and the order of presentation was randomized. In Step 2 , each panelist evaluated one sample. The sensory attributes appearance, color, aroma, flavor, and overall impression were measured using a 9-point-structured hedonic scale ( $1=$ dislike extremely, 9=like extremely). Purchase intention was also evaluated using a 5 -point-structured hedonic scale ( $1=$ certainly would not buy; $5=$ certainly would buy). Results were analyzed using ANOVA and the Tukey test at 5\% significance.

\section{Results and discussion}

\subsection{Step 1 - Quality of nectar prepared with low-fat açai pulp in comparison with nectar prepared with full-fat açai pulp}

The average physicochemical composition of the cupuaçu pulp used as raw material was as follows: total dry matter $6.82 \pm 0.51 \%$; ash $0.42 \pm 0.01 \%$; total protein $0.65 \pm 0.05 \%$; lipids $0.64 \pm 0.09 \%$; crude fiber $0.51 \pm 0.08 \%$, carbohydrates $4.59 \pm 0.23 \%$; pH $3.15 \pm 0.03$; titratable acidity $1.41 \pm 0.21 \%$ citric acid; and soluble solids $7.13 \pm 0.02{ }^{\circ}$ Brix. Total solids, soluble solids, and titratable acidity of cupuaçu pulp were not in accordance with Brazilian law, which determines a minimum of $12 \mathrm{~g} .100 \mathrm{~g}^{-1}, 9.0^{\circ} \mathrm{Brix}$, and $1.5 \%$, respectively, for this product (Brasil, 2000). Santos et al. (2010) and Freire et al. (2009) also obtained lower acidity values than the minimum required for cupuaçu pulp (1.29\% and $1.38 \%$, respectively). Regarding the soluble solid content, Freire et al. (2009) also found values lower than $9.0^{\circ}$ Brix for one of the commercial samples evaluated. These authors obtained values of total solids lower than the minimum established by law (9.36 a 10.05\%). On the other hand, the $\mathrm{pH}$ of cupuaçu pulp was in compliance with the minimum established by law (2.60) (Brasil, 2000) and was similar to the values found by Freire et al. (2009) (3.40-3.50), Canuto et al. (2010) (3.5) and Santos et al. (2010) (3.24-3.72).

Table 1 shows the physicochemical composition of açaí pulps used to prepare the nectars.

The full-fat açaí had total dry matter content of $9.98 \%$, and thus it was classified as fine or popular açaí (type C), according to Brazilian legislation (Brasil, 2000). The $\mathrm{pH}$ and the lipid content were within the range established by law (4.0-6.2 and 20-60 g.100 g-1 dry matter, respectively), but titratable acidity was higher than the maximum established for fine açaí (0.27\%) (Brasil, 2000). Oliveira et al. (2011) also found high acidity values ( $0.53 \%$ citric acid) for fine açaí and a $\mathrm{pH}$ value similar to that obtained in this experiment (4.30).

The anthocyanins content $\left(19.21 \mathrm{mg} \cdot 100 \mathrm{~g}^{-1}\right)$ was lower than that found by Borovik (2010) for fine açaí (23.39 mg.100 g $\mathrm{g}^{-1}$ ). The crude fiber content was also lower than that reported by Borovik (2010) for fine açaí (3.34\%), while the protein and lipid levels were higher than those found by this author $(0.82 \%$ and $2.95 \%$, respectively). On the other hand, the protein and lipid
Table 1. Physicochemical composition of açaí pulps used as raw material to prepare the full-fat and low-fat nectars in step 1.

\begin{tabular}{ccc}
\hline Parameter & Full-fat açaí pulp & Low-fat açaí pulp \\
\hline $\begin{array}{c}\text { Total dry } \\
\text { matter (\%) }\end{array}$ & $9.98 \pm 0.21$ & $7.32 \pm 0.19$ \\
$\begin{array}{c}\text { Total protein } \\
\text { (\%) }\end{array}$ & $0.95 \pm 0.07 / 9.50 \pm 0.71^{*}$ & $0.71 \pm 0.06 / 9.68 \pm 0.58^{*}$ \\
Lipids (\%) & $3.95 \pm 0.52 / 39.64 \pm 5.23^{*}$ & $1.94 \pm 0.33 / 26.49 \pm 3.82^{*}$ \\
Ash (\%) & $0.04 \pm 0.01 / 0.36 \pm 0.02^{*}$ & $0.03 \pm 0.01 / 0.35 \pm 0.02^{*}$ \\
Crude fiber (\%) & $1.26 \pm 0.16 / 12.63 \pm 0.49^{*}$ & $0.62 \pm 0.11 / 8.52 \pm 0.97^{*}$ \\
Carbohydrates & $3.78 \pm 0.21 / 37.87 \pm 2.55^{*}$ & $4.02 \pm 0.25 / 54.96 \pm 3.08^{*}$ \\
$\quad(\%)$ & & \\
pH & $4.34 \pm 0.03$ & $4.02 \pm 0.02$ \\
$\begin{array}{c}\text { Titratable } \\
\text { acidity (\% citric } \\
\text { acid) }\end{array}$ & $0.29 \pm 0.04$ & $0.25 \pm 0.06$ \\
$\begin{array}{c}\text { Soluble solids } \\
\left({ }^{\circ} \text { Brix) }\right.\end{array}$ & $3.33 \pm 0.03$ & \\
$\begin{array}{c}\text { Anthocyanins } \\
(\text { mg.100 g-1) }\end{array}$ & $36.38 \pm 2.25$ & $3.13 \pm 0.04$ \\
\hline${ }^{*}$ g/100g dry matter. & & $25.63 \pm 1.15$ \\
\hline
\end{tabular}

contents reported by Oliveira et al. (2011) for fine açaí sold in Rio Branco/AC (9.45 and 31.07 g. $100 \mathrm{~g}^{-1}$ of dry matter, respectively) were similar to those found in the present study. The differences between the values found in the literature regarding the chemical composition of açaí can be explained by its variability depending on the species, production area, harvest time, maturation time, and type of processing.

The low-fat açaí pulp had lipid content $50.9 \%$ lower than that of the full-fat açaí pulp. Moreover, the defatting step reduced the total dry matter, anthocyanins, and, especially, crude fiber contents, indicating that during centrifugation there was a significant loss of other components besides fat.

The defatting step was performed using a disc stack separator. Although this study did not have the objective of optimizing the centrifugation conditions, it is appropriate to make some considerations about this procedure since it influenced the results. There are very few studies in the literature on the defatting of açaí pulp. The studies found (Cruz et al., 2011; Monteiro et al., 2009) reported the use of centrifugation as a pretreatment for the microfiltration process of açai pulp, but did not provide any specific information about this pretreatment. In view of the lack of available data, several preliminary tests were conducted in order to allow the açaí pulp centrifugation. In these trials, the centrifugal separator effectively separated the fat only in the first 5-7 minutes of operation. After that, there was insoluble material deposition between the discs, making it impossible to continue the process without prior disassembly and cleaning of the equipment For the purpose of this study, the amount of raw material (low-fat açaí pulp) obtained in the first minutes of processing was enough, but the centrifugation process cannot be considered commercially viable under these conditions. It is necessary, therefore, to study alternative technologies to reduce the amount of solid material suspended in the açaí pulp in order to make the defatting step by centrifugation on a pilot scale viable. 
It should be noted that the low total solids and fiber contents obtained for the low-fat açaí pulp are probably related to the deposition of suspended material between the discs of the centrifuge. With respect to anthocyanins, the loss may have been caused by deposition of material on the equipment and also by the greater degradation of these compounds due to the longer exposure time to air-oxygen and to the temperature of $50{ }^{\circ} \mathrm{C}$ during centrifugation. Anthocyanins are extremely unstable and can be degraded during processing and storage. The main factors that influence the stability of these pigments are $\mathrm{pH}$, temperature, and the presence of oxygen and enzymes, as well as interaction with other components such as ascorbic acid, metal ions, and sugars. In general, anthocyanins are more stable at lower temperatures and in the absence of oxygen (Lopes et al., 2007; Bobbio \& Bobbio, 1992). During the defatting step, the açaí pulp was exposed to adverse conditions over a longer period of time, which probably contributed to the degradation of these compounds.

Table 2 shows the average physicochemical composition values and the energy value of full-fat and low-fat nectars. The titratable acidity, $\mathrm{pH}$, soluble solids and total dry matter content of full fat nectars were similar to those reported by Embrapa (Empresa Brasileira de Pesquisa Agropecuária, 2006) for the açaí and cupuaçu nectar $\left(0.57 \%, 3.89,17.8^{\circ}\right.$ Brix and $19.72 \%$, respectively). On the other hand, other physicochemical parameters were quite different, probably due to compositional differences of the raw material used in both studies.

The low-fat nectar had 79\% less lipids and 36.8\% less energy than the full-fat nectar. Furthermore, low-fat nectar had lower dry matter, protein, fiber, ash and anthocyanins contents than full-fat nectar, which was expected due to the difference in composition between the raw material (full-fat and low-fat açaí pulp).

All nectars were in compliance with the microbiological safety requirements, showing no contamination with total and thermotolerant coliforms or salmonella sp. This result allowed the sensory evaluations to be performed. In general, it can be said that both nectars had good sensory acceptance since they received scores above 6 for all sensory attributes (Table 3 ). However, the low-fat nectar had lower scores than the full-fat nectar $(\mathrm{p}<0.05)$ for color and appearance. This difference in color and appearance influenced the purchase intention responses since while over $70 \%$ of the panelists probably or certainly would buy the full-fat nectar, only 55\% would do it for low-fat nectar (Figure 1). Results reported by Embrapa (Empresa Brasileira de Pesquisa Agropecuária, 2006) for the açaí and cupuaçu nectar showed that the product had $81.25 \%$ of positive purchase intention, a percentage similar to that obtained in the present study.

The results of instrumental color (Table 4) showed no significant difference $(\mathrm{p}>0.05)$ between the products in the parameters $\mathrm{L}^{*}$ and $\mathrm{a}^{*}$. On the other hand, the parameter $\mathrm{b}^{*}$ was significantly higher $(\mathrm{p}<0.05)$ in the low-fat nectar, indicating that this product had a more intense yellow color than the full-fat nectar. This color difference, which resulted in lower sensory acceptance, was probably related to the lower levels of total solids, lipids, and anthocyanins found in LFN when compared to those of FFN.

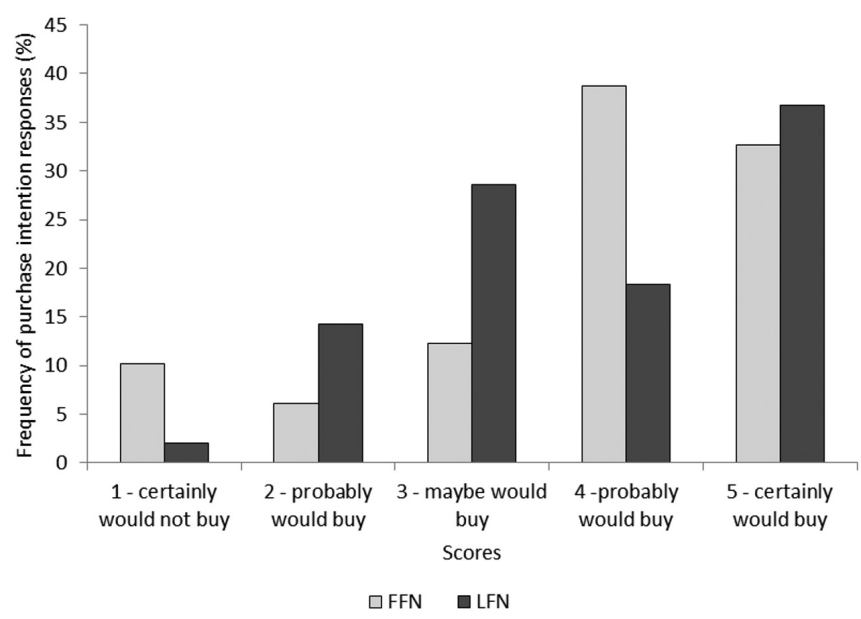

Figure 1. Histogram of purchase intention of full-fat nectars (FFN) and low-fat nectars (LFN).

Table 2. Average physicochemical composition values and energy value of the full-fat nectars (FFN) and low-fat nectars (LFN).

\begin{tabular}{|c|c|c|}
\hline Parameter & FFN & LFN \\
\hline Total dry matter (\%) & $19.27 \pm 1.43^{\mathrm{a}}$ & $14.01 \pm 0.37^{b}$ \\
\hline Total protein (\%) & $0.88 \pm 0.06^{\mathrm{a}}$ & $0.48 \pm 0.05^{b}$ \\
\hline Lipids (\%) & $3.71 \pm 1.24^{\mathrm{a}}$ & $0.77 \pm 0.01^{\mathrm{b}}$ \\
\hline Ash (\%) & $0.06 \pm 0.01^{\mathrm{a}}$ & $0.04 \pm 0.01^{\mathrm{b}}$ \\
\hline Crude fiber (\%) & $1.07 \pm 0.24^{\mathrm{a}}$ & $0.54 \pm 0.09^{b}$ \\
\hline Carbohydrates (\%) & $13.55 \pm 0.31^{\mathrm{a}}$ & $12.19 \pm 0.26^{\mathrm{a}}$ \\
\hline $\begin{array}{l}\text { Energy value } \\
\left(\mathrm{kcal} .100 \mathrm{~g}^{-1}\right)\end{array}$ & $91.11 \pm 10.90^{\mathrm{a}}$ & $57.61 \pm 1.18^{b}$ \\
\hline $\mathrm{pH}$ & $3.88 \pm 0.05^{\mathrm{a}}$ & $3.81 \pm 0.03^{\mathrm{a}}$ \\
\hline $\begin{array}{l}\text { Titratable acidity } \\
\text { (\% citric acid })\end{array}$ & $0.45 \pm 0.03^{\mathrm{a}}$ & $0.42 \pm 0.02^{a}$ \\
\hline Soluble solids $\left({ }^{\circ} \mathrm{Brix}\right)$ & $16.39 \pm 1.01^{\mathrm{a}}$ & $14.01 \pm 0.95^{\mathrm{a}}$ \\
\hline $\begin{array}{l}\text { Anthocyanins } \\
\left(\mathrm{mg}^{1} \mathbf{1 0 0 g}^{-1}\right)\end{array}$ & $19.21 \pm 1.10^{\mathrm{a}}$ & $16.46 \pm 1.47^{b}$ \\
\hline
\end{tabular}

Table 3. Average sensory evaluation scores of aroma, appearance, color, flavor, and overall impression of full-fat nectars (FFN) and lowfat nectars (LFN).

\begin{tabular}{lcc}
\hline \multicolumn{1}{c}{ Sensory Attribute } & FFN & LFN \\
\hline Aroma & $7.39 \pm 1.34^{\mathrm{a}}$ & $7.08 \pm 1.55^{\mathrm{a}}$ \\
Appearance & $7.67 \pm 1.39^{\mathrm{a}}$ & $6.73 \pm 1.69^{\mathrm{b}}$ \\
Color & $7.98 \pm 0.97^{\mathrm{a}}$ & $6.96 \pm 1.54^{\mathrm{b}}$ \\
Flavor & $6.78 \pm 2.03^{\mathrm{a}}$ & $6.86 \pm 1.80^{\mathrm{a}}$ \\
Overall impression & $6.86 \pm 1.95^{\mathrm{a}}$ & $6.88 \pm 1.68^{\mathrm{a}}$ \\
\hline
\end{tabular}

Means with the same letter in the same row do not differ significantly $(\mathrm{p}>0.05)$.

Table 4. Average values of the instrumental color parameters $L^{\star}, a^{*}$, and $b^{*}$ of the full-fat nectars (FFN) and low-fat nectars (LFN).

\begin{tabular}{crr}
\hline Color parameter & \multicolumn{1}{c}{ FFN } & \multicolumn{1}{c}{ LFN } \\
\hline $\mathbf{L}^{*}$ & $26.39 \pm 0.37^{\mathrm{a}}$ & $25.93 \pm 0.45^{\mathrm{a}}$ \\
$\mathbf{a}^{*}$ & $5.72 \pm 0.39^{\mathrm{a}}$ & $5.71 \pm 0.20^{\mathrm{a}}$ \\
$\mathbf{b}^{*}$ & $2.06 \pm 0.38^{\mathrm{b}}$ & $3.25 \pm 0.08^{\mathrm{a}}$ \\
\hline
\end{tabular}

Means with the same letter in the same row do not differ significantly $(p>0.05)$. 


\subsection{Step 2 - Changes during storage of the low-fat açaí and cupuaçu nectar}

The average physicochemical composition of the cupuaçu pulp used as raw material was as follows: total dry matter $19.30 \pm 0.88 \%$; ash $0.14 \pm 0.01 \%$; total protein $0.67 \pm 0.06 \%$; lipids $1.03 \pm 0.09 \%$; crude fiber $2.21 \pm 0.09 \%$, carbohydrates $15.25 \pm 0.97 \%$; pH $3.24 \pm 0.02$; titratable acidity $2.38 \pm 0.44 \%$ citric acid; and soluble solids $9.05 \pm 0.03^{\circ}$ Brix. The total solids, soluble solids, $\mathrm{pH}$, and titratable acidity of cupuaçu pulp were in accordance with the Brazilian law, which determines a

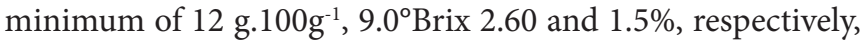
for this product (Brasil, 2000).

Table 5 shows the physicochemical composition of açaí pulps used to prepare the low-fat nectars.

The full-fat açaí pulp had total dry matter content of 13.24\%, and thus it was classified as medium açaí (type B), according to Brazilian legislation (Brasil, 2000). The $\mathrm{pH}$, lipid content, and titratable acidity were within the range established by law (4.0-6.2, 20-60 g.100 g-1 dry matter and 0.40\% maximum, respectively) (Brasil, 2000). The physicochemical composition values found are in accordance with those reported by Fregonesi et al. (2010), who evaluated 17 commercial samples of açaí type $\mathrm{B}$ and obtained the following results: ash $0.16-0.39 \%$, lipids 24.47-58.54 g.100 g dry matter, protein 8.01-10.67 g.100 g $\mathrm{g}^{-1}$

Table 5. Physicochemical composition of açaí pulps used as raw material to prepare the low-fat nectars in step 2 .

\begin{tabular}{|c|c|c|}
\hline Parameter & Full-fat açaí pulp & Low-fat açaí pulp \\
\hline $\begin{array}{c}\text { Total dry matter } \\
(\%)\end{array}$ & $13.24 \pm 0.35$ & $6.76 \pm 0.28$ \\
\hline $\begin{array}{c}\text { Total protein } \\
\text { (\%) }\end{array}$ & $1.07 \pm 0.05 / 7.99 \pm 0.49^{*}$ & $0.58 \pm 0.06 / 8.65 \pm 0.72^{\star}$ \\
\hline Lipids (\%) & $6.99 \pm 0.41 / 52.21 \pm 3.81^{*}$ & $3.08 \pm 0.28 / 45.57 \pm 3.13^{*}$ \\
\hline Ash (\%) & $0.31 \pm 0.02 / 2.32 \pm 0.03^{\star}$ & $0.23 \pm 0.02 / 3.40 \pm 0.03^{*}$ \\
\hline Crude fiber (\%) & $2.15 \pm 0.55 / 16.36 \pm 1.88^{*}$ & $0.44 \pm 0.10 / 6.47 \pm 1.16^{*}$ \\
\hline $\begin{array}{c}\text { Carbohydrates } \\
(\%)\end{array}$ & $2.73 \pm 0.62 / 21.13 \pm 5.45^{\star}$ & $2.42 \pm 0.52 / 35.91 \pm 5.77^{\star}$ \\
\hline pH & $4.28 \pm 0.03$ & $4.70 \pm 0.03$ \\
\hline $\begin{array}{c}\text { Titratable } \\
\text { acidity } \\
\text { (\% citric acid) }\end{array}$ & $0.20 \pm 0.05$ & $0.25 \pm 0.08$ \\
\hline $\begin{array}{c}\text { Soluble solids } \\
\left({ }^{\circ} \text { Brix }\right)\end{array}$ & $4.80 \pm 0.03$ & $3.75 \pm 0.02$ \\
\hline $\begin{array}{l}\text { Anthocyanins } \\
\left(\mathbf{m g} .100 \mathrm{~g}^{-1}\right)\end{array}$ & $30.78 \pm 2.85$ & $19.48 \pm 2.03$ \\
\hline
\end{tabular}

dry matter, fiber 0.69-4.57\%, carbohydrates 0.70-4.65 g. $100 \mathrm{~g}^{-1}$, and acidity $0.11-0.52 \%$ citric acid. The content of anthocyanins (30.78 mg.100 g $\mathrm{g}^{-1}$ ) was higher than that found by Borovik (2010) for fine açaí (23.39 mg.100 g-1) and higher than the values found for full-fat açaí pulp in the first step (Table 1). Fregonesi et al. (2010) showed that there is great variability in the composition of commercially available açaí pulps. This result was confirmed in the present study since the composition of açaí pulp used in the second step differed greatly from that of the açaí used in the first step. Since the two raw materials were obtained in the same region and acquired from the same producer/processor, this difference can be attributed to differences in harvest season and/or maturation stage or to the lack of standardization of the processing conditions.

The low-fat açaí pulp had lipid content 55.9\% lower than that of the full-fat açaí pulp. Like what occurred in the first step, the defatting step reduced the total dry matter, anthocyanins, and crude fiber contents.

The average chemical composition of the low-fat nectars was as follows: total dry matter $15.16 \pm 1.30 \%$; ash $0.04 \pm 0.01 \%$; total protein $0.55 \pm 0.12 \%$; lipids $0.89 \pm 0.54 \%$; crude fiber $2.23 \pm 0.87 \%$, and carbohydrates $11.44 \pm 0.33 \%$. The mean energy value was $55.97 \pm 2.16 \mathrm{kcal} 100 \mathrm{~g}^{-1}$. As shown in Figure 2, the anthocyanin content decreased over time $(\mathrm{p}<0.05)$ and there was no difference in soluble solids, $\mathrm{pH}$, and titratable acidity over time. Pacheco-Palencia et al. (2007) also observed a reduction in the total anthocyanins content of açaí during storage at $20^{\circ} \mathrm{C}$.

Regarding instrumental color, the intensity of the yellow color (parameter $\left.b^{\star}\right)$ increased during storage $(p<0.05)$ (Table 6). A similar result was found by Alexandre et al. (2004), who observed an increase in the values of the color parameter $b^{*}$ for açaí pulp during storage at $25^{\circ} \mathrm{C}$. The increase in the intensity of the yellow color was probably related to degradation or transformation of anthocyanins since they are the main compounds responsible for the açaí fruit color. As previously explained, anthocyanins are extremely unstable and are particularly affected by factors such as $\mathrm{pH}$, temperature, interaction with air-oxygen, enzymes, ascorbic acid, metal ions, and sugars (Lopes et al., 2007). Pacheco-Palencia et al. (2007) reported an increase in the polymerization of anthocyanins of açaí during storage at $20^{\circ} \mathrm{C}$. According to these authors, monomeric anthocyanins are responsible for the color purple present in fruits, but polymerized anthocyanins make them turn into a brownish color. Pacheco-Palencia et al. (2007) also found that the presence of ascorbic acid in açaí significantly increased polymerization of anthocyanins, which probably had a deleterious effect on the product color. In the present study,

Table 6. Average values of instrumental color parameters $\mathrm{L}^{\star}, \mathrm{a}^{\star}$, and $\mathrm{b}^{\star}$ of low-fat nectars as a function of storage time at $25^{\circ} \mathrm{C}$.

\begin{tabular}{|c|c|c|c|c|c|c|c|}
\hline \multirow{2}{*}{ Color parameter } & \multicolumn{7}{|c|}{ Storage time (days) } \\
\hline & 0 & 30 & 60 & 90 & 120 & 150 & 180 \\
\hline $\mathbf{L}^{*}$ & $28.30 \pm 1.21^{\mathrm{a}}$ & $28.07 \pm 0.95^{\mathrm{a}}$ & $28.02 \pm 1.06^{\mathrm{a}}$ & $28.26 \pm 1.07^{\mathrm{a}}$ & $28.09 \pm 1.18^{\mathrm{a}}$ & $28.52 \pm 1.24^{\mathrm{a}}$ & $28.70 \pm 1.17$ \\
\hline$a^{*}$ & $6.09 \pm 0.79^{\mathrm{a}}$ & $5.80 \pm 0.85^{\mathrm{a}}$ & $5.79 \pm 0.91^{\mathrm{a}}$ & $5.84 \pm 0.90^{\mathrm{a}}$ & $5.80 \pm 0.91^{\mathrm{a}}$ & $6.07 \pm 0.92^{\mathrm{a}}$ & $6.18 \pm 0.99^{2}$ \\
\hline $\mathbf{b}^{*}$ & $3.78 \pm 1.33^{\mathrm{a}}$ & $3.77 \pm 1.33^{\mathrm{a}}$ & $3.80 \pm 1.36^{\mathrm{a}}$ & $3.87 \pm 1.35^{\mathrm{a}}$ & $4.10 \pm 1.43^{\mathrm{ab}}$ & $4.14 \pm 1.46^{\mathrm{ab}}$ & $4.49 \pm 1.60^{l}$ \\
\hline
\end{tabular}

Means with the same letter in the same row do not differ significantly $(\mathrm{p}>0.05)$ 


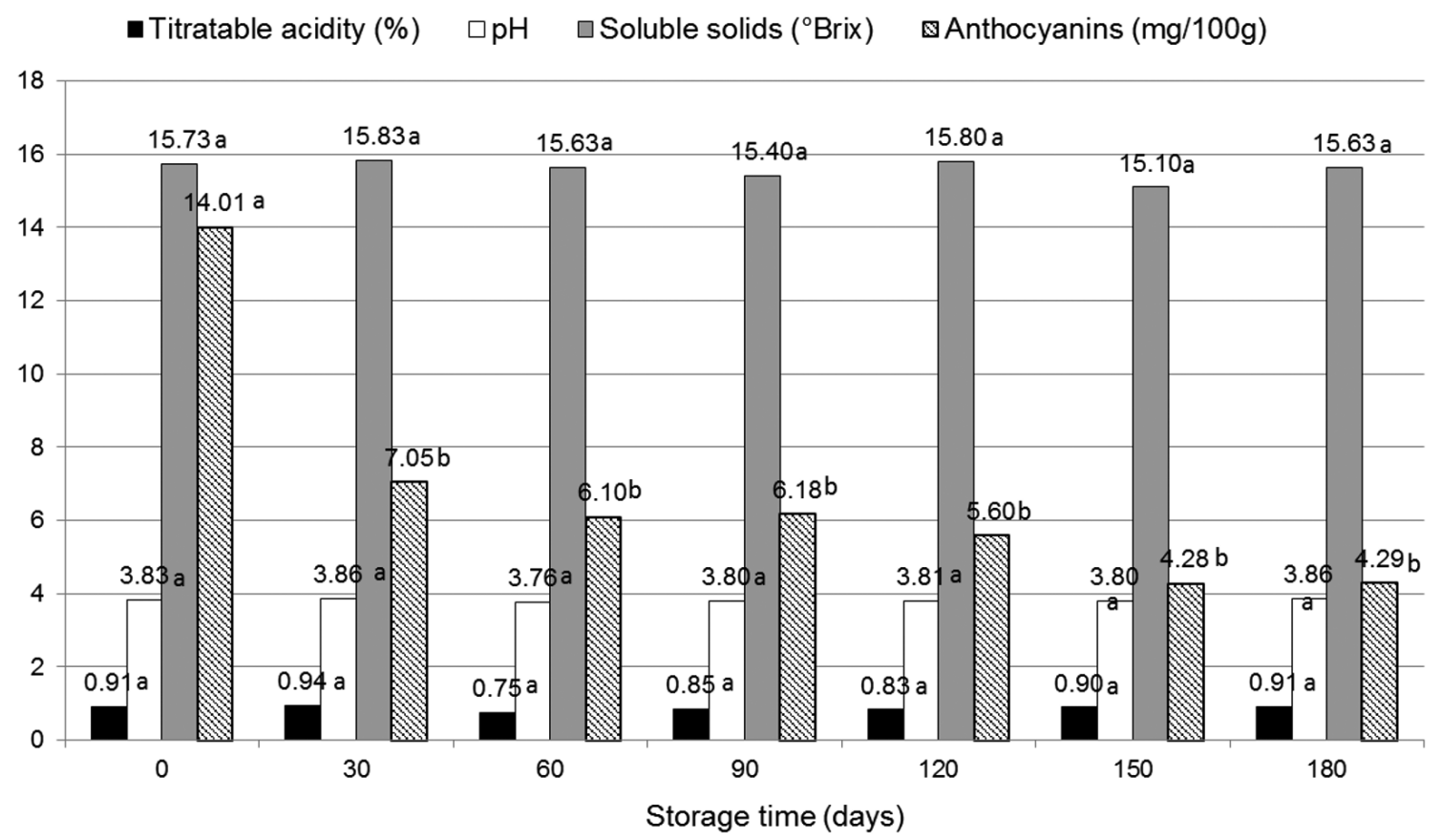

Figure 2. Average values of titratable acidity, $\mathrm{pH}$, soluble solids, and anthocyanin contents of low-fat nectars as a function of storage time. Means with the same letter in the same variable do not differ significantly $(\mathrm{p}>0.05)$.

the results suggest that the anthocyanins were affected by both storage at relatively high temperature $\left(25^{\circ} \mathrm{C}\right)$ and interaction with ascorbic acid, which is present in the cupuaçu pulp.

Is worth noting that, although the nectar was subjected to intense heat treatment $\left(115^{\circ} \mathrm{C} / 10\right.$ minutes $)$, the anthocyanins content right after preparation of the nectar (14.01 mg.100 g $\left.{ }^{-1}\right)$ did not differ significantly from that of the low-fat açaí pulp $\left(19.48 \mathrm{mg} .100 \mathrm{~g}^{-1}\right)$. This slight difference seems to be related more to the mass balance than to the heat treatment. Although most of the available studies indicate that thermal treatment reduces the levels of bioactive compounds, there is still controversy about it (Rawson et al., 2011). Albarici \& Pessoa (2012) showed that pasteurization at $90^{\circ} \mathrm{C}$ for 30 seconds reduced the degradation rate of anthocyanins compared to that of the unpasteurized pulp. On the other hand, these authors also demonstrated the importance of using low temperatures during processing and storage to increase the stability of anthocyanins. The results obtained in the present study showed that the prolonged storage at $25^{\circ} \mathrm{C}$ and the possible interactions between anthocyanins and other components of the nectars had more significant effect on the degradation of these compounds than did the thermal treatment performed.

There was no evidence of the presence of total and thermotolerant coliforms or salmonella during the storage of the nectars. This result allowed the sensory evaluations to be performed. The samples showed good sensory acceptance during the studied period, with scores higher than 6.0 for all sensory attributes evaluated (appearance, aroma, color, flavor, and overall impression) (Table 7). Nevertheless, the color scores gradually decreased over time; thus, the score on day 180 was significantly lower than that on days 0 and 60 . This result was
Table 7. Average sensory evaluation scores of aroma, appearance, color, flavor and overall impression of the low-fat nectars as a function of storage time at $25^{\circ} \mathrm{C}$.

\begin{tabular}{lcccc}
\hline \multirow{2}{*}{$\begin{array}{c}\text { Sensory } \\
\text { attribute }\end{array}$} & \multicolumn{4}{c}{ Storage time (days) } \\
\cline { 2 - 5 } \multicolumn{1}{c}{$\mathbf{0}$} & $\mathbf{6 0}$ & $\mathbf{1 2 0}$ & $\mathbf{1 8 0}$ \\
\hline Appearance & $6.82 \pm 1.57^{\mathrm{a}}$ & $6.79 \pm 1,50^{\mathrm{a}}$ & $6.59 \pm 1.52^{\mathrm{a}}$ & $6.45 \pm 1.56^{\mathrm{a}}$ \\
Color & $7.06 \pm 1.52^{\mathrm{a}}$ & $7.00 \pm 1,54^{\mathrm{a}}$ & $6.41 \pm 1.81^{\mathrm{ab}}$ & $6.09 \pm 1.77^{\mathrm{b}}$ \\
Aroma & $6.68 \pm 1.66^{\mathrm{a}}$ & $6.62 \pm 1.63^{\mathrm{a}}$ & $6.91 \pm 1.71^{\mathrm{a}}$ & $6.00 \pm 2.14^{\mathrm{a}}$ \\
Flavor & $7.09 \pm 1.68^{\mathrm{a}}$ & $6.69 \pm 1.71^{\mathrm{a}}$ & $7.06 \pm 1.56^{\mathrm{a}}$ & $6.24 \pm 2.35^{\mathrm{a}}$ \\
$\begin{array}{l}\text { Overall } \\
\text { impression }\end{array}$ & $7.26 \pm 1.29^{\mathrm{a}}$ & $6.86 \pm 1.55^{\mathrm{a}}$ & $6.84 \pm 1.83^{\mathrm{a}}$ & $6.48 \pm 1.95^{\mathrm{a}}$ \\
\hline
\end{tabular}

probably due to the degradation and/or transformation of the anthocyanins, which resulted in an increase in the intensity of yellow color (Figure 2 and Table 6). For the other sensory attributes evaluated, there was no significant difference over time $(\mathrm{p}>0.05)$.

Figure 3 shows the histogram of purchase intention of the nectars at $0,60,120$, and 180 days of storage. Up to 120 days of storage, the positive purchase intent (responses that corresponded to "probably or certainly would buy") was quite high, ranging between 60 and $75 \%$, while the negative purchase intent (responses that corresponded to "probably or certainly would not buy") was low, between 5 and 14\%. At 180 days, on the other hand, the positive purchase intent was much lower (52\%), while the negative purchase intent was more significant, demonstrated by almost $25 \%$ of the panelists. This result indicates lower acceptance of the product regarding color after 6 months of storage. Therefore, from a sensory point of view, the recommended shelf life of this product is up to 120 days. 


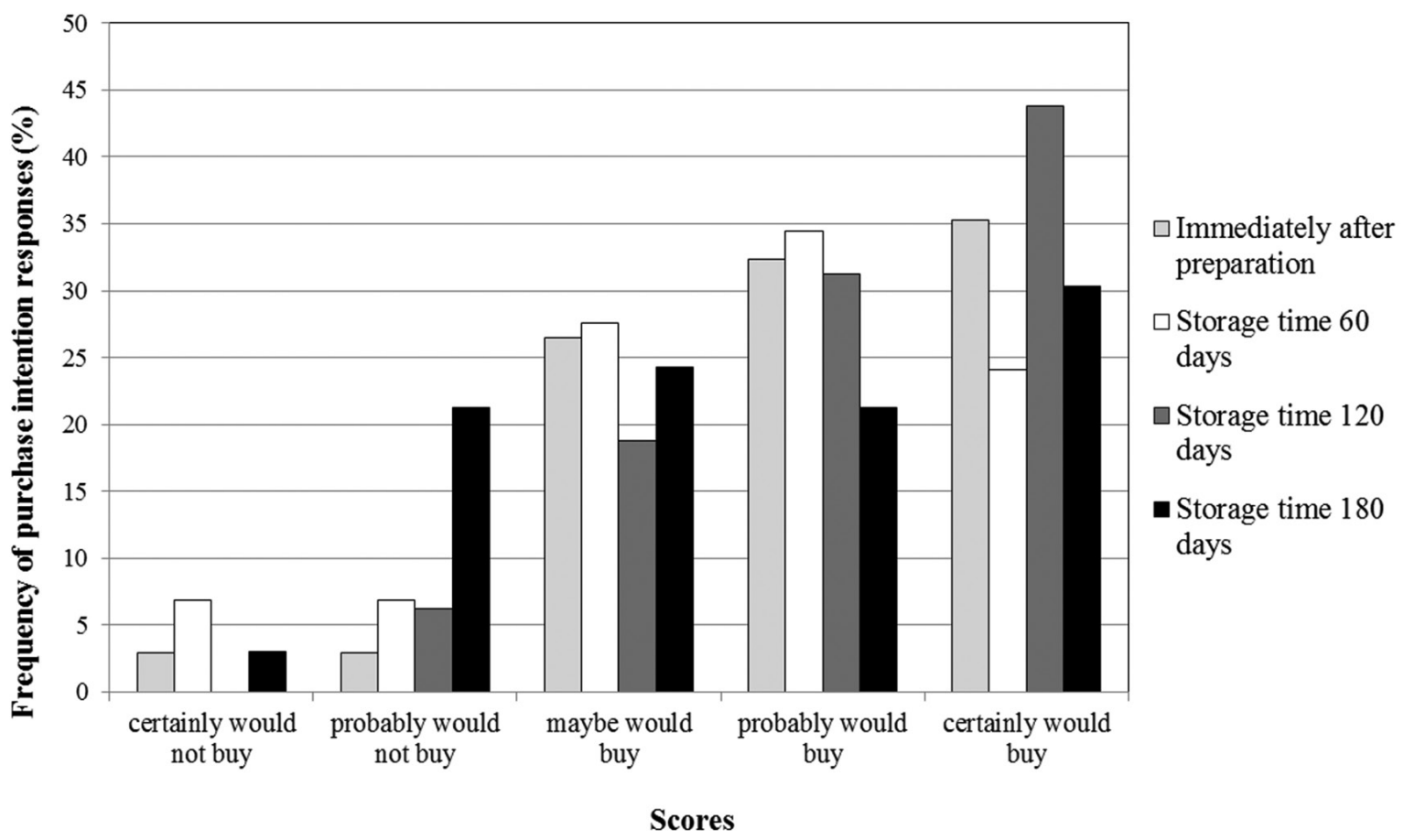

Figure 3. Histogram of purchase intention of low-fat nectars as a function of storage time.

\section{Conclusions}

The defatting process of açaí pulp needs to be improved in order to minimize the loss of components other than lipids, in particular fibers and anthocyanins. The use of defatted açaí pulp as a raw material resulted in açaí and cupuaçu nectars with good sensory acceptance, but with lower acceptance than the full-fat nectar in terms of color and appearance. With regard to the changes during storage of the low-fat nectar for up to 180 days, there was degradation and/or transformation of anthocyanins, which changed the color of the product and reduced its sensory acceptance. Under the preparation and storage conditions used in this experiment, the recommended shelf life of this product is up to 120 days.

\section{Acknowledgements}

The authors are grateful for the financial support provided by Funtac (Fundação de Tecnologia do Estado do Acre).

\section{References}

Albarici, T. R., \& Pessoa, J. D. C. (2012). Effects of heat treatment and storage temperature on the use of açaí drink by nutraceutical and beverage industries. Ciência e Tecnologia de Alimentos, 32(1), 9-14.

Alexandre, D., Cunha, R. L., \& Hubinger, M. D. (2004). Conservação do açaí pela tecnologia de obstáculos. Ciência e Tecnologia de Alimentos, 24(1), 114-119. http://dx.doi.org/10.1590/S010120612004000100021.

Association of Offical Analitical Chemists - AOAC. (1998). Official methods of analysis of the Association of Official Analitical Chemists (15th ed.). Washington: AOAC International.
Bobbio, G. O., \& Bobbio, P. A. (1992). Quimica do processamento de alimentos (2nd ed.). São Paulo: Editora Varela.

Borovik, C. P. B. (2010). Fracionamento de polpa de açaí e concentração de antocianinas utilizando membranas poliméricas (Dissertação de mestrado). Faculdade de Engenharia de Alimentos, Universidade Estadual de Campinas, Campinas.

Brasil, Ministério da Agricultura, Pecuária e Abastecimento. (2000, January 10). Aprova o Regulamento Técnico Geral para Fixação dos Padrões de Identidade e Qualidade para Polpa de Fruta (Instrução Normativa no 1 , de 7 de janeiro de 2000). Diário Oficial [da] República Federativa do Brasil.

Brasil, Ministério da Saúde. (2001, January 10). Aprova o Regulamento Técnico sobre Padrões Microbiológicos para Alimentos (ResoluçãoRDC $n^{\circ} 12$, de 2 de janeiro de 2001). Diário Oficial [da] República Federativa do Brasil.

Canuto, G. A. B., Xavier, A. A. O., Neves, L. C., \& Benassi, M. T. (2010). Caracterização físico-química de polpas de frutos da Amazônia e sua correlação com a atividade anti-radical livre. Revista Brasileira de Fruticultura, 32(4), 1196-1205. http://dx.doi. org/10.1590/S0100-29452010005000122.

Carvalho, A. V. (2007). Otimização dos parâmetros tecnológicos para produção de estruturados de frutas funcionais a partir de polpa de açaí e "mix" de taperebá com mamão. Belém: Embrapa Amazônia Oriental.

Cruz, A. P. G., Mattietto, R. A., Taxi, C. M. A. D., Cabral, L. M. C., Donangelo, C. M., \& Matta, V. M. (2011). Effect of microfiltration on bioactive components and antioxidant activity of açaí (Euterpe oleracea Mart.). Desalination and Water Treatment, 27(1-3), 97102. http://dx.doi.org/10.5004/dwt.2011.2064.

Del Pozo-Insfran, D., Percival, S. S., \& Talcott, S. T. (2006). Açaí (Euterpe oleracea) polyphenolics in their glycoside and aglycone forms 
induce apoptosis of HL-60 leukemia cells. Journal of Agricultural and Food Chemistry, 54(4), 1222-1229. http://dx.doi.org/10.1021/ jf052132n. PMid:16478240.

Empresa Brasileira de Pesquisa Agropecuária - EMBRAPA. Centro Nacional de Pesquisa Agropecuária. (2006). Néctar misto de açai, processo de produção e de conservação: Patente BR No. PI 04044576. Rio de Janeiro: INPI.

Francis, F. J. (1982). Analysis of anthocyanins. In P. Markakis (Ed.), Anthocyanins as food colors (pp. 181-207). New York: Academic Press.

Fregonesi, B. M., Yokosawa, C. E., Okada, I. A., Massafera, G., Costa, T. M. B., \& Prado, S. P. T. (2010). Polpa de açaí congelada: características nutricionais, físicoquímicas, microscópicas e avaliação da rotulagem. Revista do Instituto Adolfo Lutz, 69(3), 387-395.

Freire, M. T. A., Petrus, R. R., Freire, C. M. A., Oliveira, C. A. F., Felipe, A. A. P. F., \& Gatti, J. B. (2009). Caracterização físicoquímica, microbiológica e sensorial de polpa de cupuaçu congelada (Theobroma grandiforum Schum). Brazilian Journal of Food Technology, 12(1), 9-16.

Intituto Adolfo Lutz - IAL. (1985). Normas analíticas do Instituto Adolfo Lutz: métodos químicos e físicos para análise de alimentos (3rd ed., Vol. 1). São Paulo: IMESP.

Lopes, T. J., Xavier, M. F., Quadri, M. G. N., \& Quadri, M. B. (2007). Antocianinas: uma breve revisão das características estruturais e da estabilidade. Revista Brasileira de Agrociência, 13(3), 291-297.

Meilgaard, M., Civille, G. V., \& Carr, B. T. (2006). Sensory evaluation techniques (4th ed., 448 p.). Boca Raton: CRC Press.

Menezes, E. M. S., Torres, A. T., \& Sabaa Srur, A. U. (2008). Valor nutricional da polpa de açaí (Euterpe oleracea Mart) lioflizada. Acta Amazonica, 38(2), 311-316. http://dx.doi.org/10.1590/S004459672008000200014.

Monteiro, F. S., Gomes, F. S., Mattietto, R. A., \& Cabral, L. M. C. (2009). Effect of pre-treatment on açaí pulp microfiltration process. In European Federation of Food Science and Technology Conference (EFFoST), Budapest, Hungary.

Oliveira, P. A. A. C., Silva, I. G., Souza, M. L., Furtado, C. M., \& Silva, R. F. (2011). In natura açaí beverage: quality, pasteurization and acidification. Ciência e Tecnologia de Alimentos, 31(2), 502-507. http://dx.doi.org/10.1590/S0101-20612011000200035.
Pacheco-Palencia, L. A., Duncan, C. E., \& Talcott, S. T. (2009). Phytochemical composition and thermal stability of two commercial açai species, Euterpe oleracea and Euterpe precatoria. Food Chemistry, 115(4), 1199-1205. http://dx.doi.org/10.1016/j. foodchem.2009.01.034.

Pacheco-Palencia, L. A., Hawken, P., \& Talcott, S. T. (2007). Phytochemical, antioxidant and pigment stability of açai (Euterpe oleracea Mart.) as affected by clarification, ascorbic acid fortification and storage. Food Research International, 40(5), 620-628. http:// dx.doi.org/10.1016/j.foodres.2006.11.006.

Queiroz, M., Cunha, S. C., \& Rogez, H. (1998). Impacto da pasteurização no suco de açaí (Euterpe Oleracea Mart.) sobre a atividade da peroxidase. In Livro de Resumos do Congresso da Associação Brasileira de Química. São Luís, Brasil.

Rawson, A., Patras, A., Tiwari, B. K., Noci, F., Koutchma, T., \& Brunton, N. (2011). Effect of thermal and non thermal processing technologies on the bioactive content of exotic fruits and their products: review of recent advances. Food Research International, 44(7), 1875-1887. http://dx.doi.org/10.1016/j.foodres.2011.02.053.

Rogez, H. (2000). Açaí: preparo, composição e melhoramento da conservação (313 p.). Belém: Universidade Federal do Pará.

Santos, G. M., Maia, G. A., Sousa, P. H. M., Figueiredo, R. W., Costa, J. M. C., \& Fonseca, A. V. V. (2010). Atividade antioxidante e correlações com componentes bioativos de produtos comerciais de cupuaçu. Ciência Rural, 47(7), 1636-1642. http://dx.doi.org/10.1590/S010384782010005000103.

Sousa, M. A. C., Yuyama, L. K. O., Aguiar, J. P. L., \& Pantoja, L. (2006). Suco de açaí (Euterpe oleracea Mart.): avaliação microbiológica, tratamento térmico e vida de prateleira. Acta Amazonica, 36(4), 483-496.

Souza, C. L., Melo, G. M. C., \& Almeida, S. C. S. (1999). Avaliação da qualidade do açaí (Euterpe oleracea Mart.) comercializado na cidade de Macapá - AP. Boletim CEPPA, 17(2), 127-136.

Tonon, R. V., Brabet, C., \& Hubinger, M. D. (2009). Infuência da temperatura do ar de secagem e da concentração de agente carreador sobre as propriedades físico-químicas do suco de açaí em pó. Ciência e Tecnologia de Alimentos, 29(2), 444-450. http:// dx.doi.org/10.1590/S0101-20612009000200034.

Vanderzant, C., \& Splittstoesser, D. F. (1992). Compendium of methods for the microbiological examination of foods (3rd ed., 1219 p.). Washington: American Public Health Association. 